\title{
PENGEMBANGAN MODUL GEOMETRI ANALITIK BIDANG BERBASIS CONTEXTUAL TEACHING LEARNING (CTL) UNTUK MENINGKATKAN KOMPETENSI MAHASISWA UNIVERSITAS RIAU KEPULAUAN (UNRIKA)
}

\author{
Yesi Gusmania dan Tubagus Pamungkas \\ Dosen Tetap FKIP Universitas Riau Kepulauan Batam
}

\begin{abstract}
Pursuant to class perception of at program of study of education of mathematics of University of Riau Archipelago ( UNRIKA) that student not yet owned the source learn adequate to support the study process in class. During the time, teaching materials used not yet effective because amount of student of many and heterogeneous in character. For a while there is no practical teaching materials from lecturer as book of student hold in the lecturing. providing product in the form of Analytic geometry module of area base on the Contextual Teaching Learning (CTL) valid, praktikalitas, and effective to increase interest of student of Program of Study of Education of Mathematics of University of Riau Archipelago ( UNRIKA).

This Research procedure use the model of Instruksional Development Institute ( IDI) consisted of by 3 phase, that is phase analyse the muka-belakang At prototype phase conducted by two phase that is phase of validasi and praktikalitas. Tahap effectiveness is assessment phase, where [at] this phase is investigated to through the activity observation and result of learning student. This research in conducting at Program of Study of Education of Mathematics of University of Riau of Archipelago of Analytic eye kuliah Geometry of Area that is semester student 3 summed uply 37 student people.

Result of this research indicate that the result validasi from validator show the module base on the CTL developed at Analytic Geometry lecturing of Area is valid, Praktikalitas Module base on the CTL can generate the enthusiasm learn and creativity berfikir of because is easy to comprehended and like hence it. Efektifitas perceived at lecturing execution by using this module is activity and result of learning student. From deskripsi of result of learning semester student 3 Program of Study of Education of generation Mathematics 2014 A obtained more than $70 \%$ student get the value more than 65 . This means module can be told effective.
\end{abstract}

\section{Keyword : Analytic Geometry Module of Area, Student Interest}

\section{PENDAHULUAN}

Geometri menempati posisi khusus dalam kurikulum matematika baik di sekolah maupun di Perguruan Tinggi, karena banyak konsep-konsep yang termuat didalamnya. Dari sudut pandang matematika, geometri menyediakan pendekatan-pendekatan untuk pemecahan masalah misalnya gambar-gambar (Ismail, 2010). Tujuan pembelajaran geometri adalah agar mahasiswa mempunyai rasa percaya diri mengenai kompetensi matematis, di antaranya 
pemecahan masalah, berkomunikasi dan bernalar secara matematis. Melihat pentingnya peranan geometri maka, geometri dijadikan salah satu materi yang diajarkan pada setiap jenjang pendidikan dan juga merupakan salah satu mata kuliah yang diajarkan kepada mahasiswa pendidikan matematika di Universitas Riau Kepulauan.

Berdasarkan pengamatan dikelas pada program studi pendidikan matematika Universitas Riau Kepulauan (UNRIKA) bahwa mahasiswa belum memiliki sumber belajar yang memadai untuk mendukung proses pembelajaran di kelas. Dalam perkuliahan selama ini, bahan ajar yang digunakan belum efektif karena jumlah mahasiswa banyak dan sifatnya heterogen. Sementara belum ada satupun bahan ajar yang praktis dari dosen sebagai buku pegangan mahasiswa dalam perkuliahan tersebut. Realitanya, hal ini sangat sulit untuk mencapai proses pembelajaran yang efektif seperti yang diharapkan, mereka mengalami kesulitan dalam memahami buku yang ada. Selain itu, bahasa pada buku sulit untuk mereka pahami. Sehingga pada umumnya mereka hanya bergantung untuk mencatat materi maupun soal dan pembahasan yang diberikan dosen selama perkuliahan. Pada saat perkuliahan mereka berharap bahwa ada suatu buku pegangan yang dibuat oleh dosen yang dimilikinya terutama pembuatan bahan ajar yang dapat menjembatani keragaman kemampuan mereka, dan mudah dipahami atau mudah untuk mereka pelajari, menarik serta efektif bagi mahasiswa.

Tujuan dari penelitian ini sebagai berikut:

1. Untuk menghasilkan produk berupa modul Geometri Analitik Bidang berbasis CTL yang valid, praktis dan efektif, untuk mahasiswa Program Studi Pendidikan Matematika Universitas Riau Kepulauan.

1. Untuk mengetahui kompetensi mahasiswa Program Studi Pendidikan Matematika Universitas Riau Kepulauan dengan pengembangan modul Geometri Analitik Bidang berbasis CTL.

\section{METODE PENELITIAN}

Pengembangan modul pembelajaran matematika dalam pengembangan ini dengan menggunakan model prosedural Instruksional Development Institute (IDI) yang terdiri dari : tahap penentuan (define) dengan menganalisis kebutuhan, tahap prototipe (validasi dan praktikalitas), dan tahap evaluasi (evaluate). Model IDI dipilih karena model dengan pendekatan sistem sesuai dengan masalah yang melatar belakangi dalam penelitian ini. Untuk mengetahui efektivitas modul Geometri Analitik Bidang berbasis CTL yang akan dirancang, 
akan digunakan penelitian pra-eksperimental dengan model rancangan penelitiannya theoneshot case study (Sumadi, 2004:100). Pada penelitian ini yang diamati adalah aktivitas mahasiswa selama proses pembelajaran dan hasil belajar mahasiswa setelah mengikuti proses pembelajaran dengan menggunakan modul Geometri Analitik Bidang berbasis CTL.

Berdasarkan model pengembangan IDI, rancangan prosedur pengembangan ini terdiri dari 3 tahap, yaitu:

1. Analisis muka-belakang (front-end analysis)

2. Tahap Prototipe (prototype)

3. Tahap Penilaian (assesment)

Secara umum, rancangan penelitian dapat dilihat pada Gambar 1berikut :

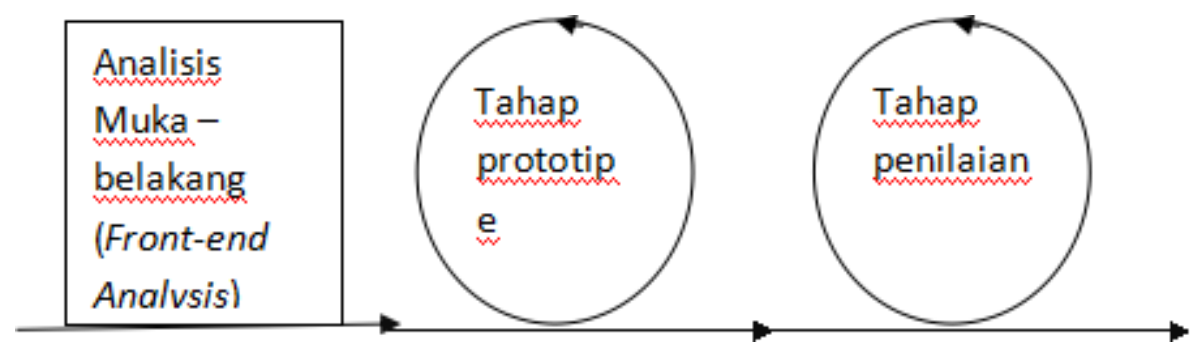

Gambar 1. Rancangan Penelitian (Ahmad, 2002:63)

\subsubsection{Tahap Analisis Muka-belakang (Front-End Analysis)}

a. Menganalisis silabus mata kuliah Geometri Analitik Bidang yang bertujuan untuk mengetahui apakah materi yang diajarkan sudah sesuai dengan kompetensi yang diharapkan.

b. Menganalisis dan mereview buku rujukan untuk mata kuliah Geometri Analitik Bidang yang bertujuan untuk melihat isi buku, cara penyajian, soal-soal latihan dan tugas-tugas, dengan tujuan apakah sudah sesuai dengan silabus mata kuliah yang berlaku.

c. Melakukan wawancara dengan teman sejawat yang bertujuan untuk mengetahui masalah apa saja yang dihadapi di lapangan sehubungan dengan perkuliahan Geometri Analitik Bidang.

d. Mempelajari karakteristik mahasiswa untuk memudahkan menyusun tingkat bahasa dalam modul dan kesukaran soal.

\subsubsection{Tahap Prototipe}

Pembuatan prototipe ini dilakukan melalui dua tahap berikut ini: 


\subsubsection{Tahap Validasi}

\subsubsection{Tahap Praktikalitas}

\subsubsection{Tahap Penilaian (assessment)}

\section{Tahap Persiapan}

Hal-hal yang perlu dipersiapkan sebelum uji coba produk adalah sebagai berikut.

a) Menentukan jadwal penelitian

b) Melihat kurikulum yang dipakai .

c) Memvalidasi instrumen penelitian kepada validator, hingga diperoleh instrumen yang valid.

d) Merancang modul berbasis CTL, Selanjutnya modul tersebut divalidasi oleh validator.

\section{Tahap Pelaksanaan}

Pada tahap pelaksanaan dilakukan kegiatan-kegiatan sebagai berikut.

a. Pendahuluan

Kegiatan-kegiatan yang dilakukan pada tahap pendahuluan adalah sebagai berikut.

1) Mengkomunikasikan topik yang akan dipelajari kepada mahasiswa.

2) Membagikan modul kepada masing-masing mahasiswa.

3) Menjelaskan manfaat mempelajari pokok bahasan serta kemampuan yang diharapkan dimiliki mahasiswa.

b. Penyajian

c. Penutup

\section{Tahap Akhir}

Pada tahap ini, dilakukan kegiatan-kegiatan sebagai berikut.

a. Melakukan revisi modul berdasarkan hal-hal yang ditemukan pada saat melakukan uji coba.

b. Menghitung persentase keaktifan

\subsubsection{Subjek Uji Coba}

Subjek uji coba dalam penelitian pengembangan ini adalah mahasiswa Program Studi Pendidikan Matematika Universitas Riau Kepulauan yang mengambil 
mata kuliah Geometri Analitik Bidang yaitu mahasiswa semester 3 dengan jumlah 35 orang mahasiswa.

\subsubsection{Jenis Data}

Ada dua jenis data, yaitu data kualitatif dan data kuantitatif. Data kualitatif diperoleh dari hasil wawancara saat uji coba, yang berupa masukan, kritik dan saran. Sedangkan data yang bersifat kuantitatif yang berupa peniliaian, dihimpun melalui hasil uji ahli dan uji coba produk pada saat kegiatan uji coba dilapangan.

\subsection{Teknik Analisis Data}

Data yang diperoleh terdiri dari data validitas, praktikalitas dan efektivitas. Data validitas dieroleh dari lembar validasi modul, data praktikalitas diperoleh dari lembar observasi pelaksanaan perkuliahan dan pedoman wawancara.

\subsubsection{Analisis Validasi}

Hasil validasi dari validator terhadap seluruh aspek yang dinilai, disajikan dalam bentuk Tabel. Selanjutnya dicari persentase skor tersebut dengan menggunakan rumus :

$$
P=\frac{\text { homlohskor padabuti tersebut }}{\text { Jonlohshor molsind }} \times 100 \%
$$

Dengan, P : Persentase

\subsubsection{Analisis Praktikalitas}

3.3.2.1 Observasi praktikalitas pelaksanaan perkuliahan dengan modul

Hasil observasi dipisah-pisahkan menurut kelompok data.Untuk menggambarkan data hasil observasi dianalisis secara kuantitatif dan kualitatif.

Untuk menentukan kriteria persentase peritem menggunakan rumus:

$$
p=\frac{\sum \text { skor peritem }}{\text { skormakxn validotor per item }} x 100 \%
$$

Tabel 5. Kategori Hasil Penilaian Validator/ Pengamat (Observer) dalam Persentase

\begin{tabular}{|l|l|}
\hline Interval (\%) & Kategori \\
\hline $0-20$ & Tidak baik \\
\hline $21-40$ & Kurang baik \\
\hline $41-60$ & Cukup \\
\hline $61-80$ & Baik \\
\hline $81-100$ & Sangat baik \\
\hline
\end{tabular}




\subsubsection{Wawancara}

Teknik deskriptif digunakan untuk menggambarkan data hasil wawancara dengan mahasiswa mengenai praktikalitas modul.Miles dan Huberman dalam Nyimas (2007: 62) menyatakan "bahwa hasil wawancara dari para pakar menghasilkan data kualitatif berdasarkan transkripsi tertulis dan catatan yang dibuat saat wawancara berlangsung”.

Miles menyatakan cara menganalisis data kualitatif terdiri dari tiga tahap, yaitu mereduksi data, penyajian data, dan penarikan kesimpulan.

\subsubsection{Analisis Efektivitas}

\subsubsection{Lembar Observasi Aktivitas Mahasiswa}

Data observasi diperoleh dengan cara menghitung jumlah mahasiswa yang melakukan aktivitas sebagaimana terdapat pada lembar observasi. Data tersebut dianalisis dengan teknik persentase yang dinyatakan oleh Sudijono (2005: 43) sebagai berikut:

Keterangan:

$$
\begin{aligned}
& P=\text { persentase aktivitas } \\
& f=\text { frekuensi aktivitas } \\
& N=\text { jumlah mahasiswa }
\end{aligned}
$$

Untuk mengetahui tingkat keberhasilan aktivitas belajar mahasiswa, Dimyati (2006: 125) memberikan kriteria sebagai berikut:

Tabel 6. Kriteria Keberhasilan Aktivitas Belajar Mahasiswa

\begin{tabular}{|l|l|l|}
\hline Kriteria & Tingkat keberhasilan & Range persentase \\
\hline Sedikit sekali & Tidak berhasil & 25 \\
Sedikit & Kurang berhasil & 2550 \\
Banyak & Berhasil & 5075 \\
Banyak sekali & Sangat berhasil & 75 \\
\hline
\end{tabular}

Sumber: Dimyati (2006: 125)

\subsubsection{Tes Hasil Belajar}

Data yang diperoleh dari tes hasil belajar dianalisis dengan menggunakan perhitungan persentase mahasiswa. Untuk melihat efektif atau tidaknya modul yang dikembangkan perlu diadakan tes, jika lebih dari 70\% mahasiswa mendapatkan nilai $\geq 65$ maka pengembangan modul dapat dikatakan efektif.

\section{HASIL PENELITIAN DAN PEMBAHASAN}

\section{Validitas Modul}


segi aspek materi Persentase tingkat pencapaian $82,14 \%$ berada pada kualifikasi sangat valid. Persentase tingkat pencapaian $82,14 \%$ berada pada kualifikasi sangat valid.

segi Penyajian, persentase tingkat pencapaian $81,43 \%$ berada pada kualifikasi sangat valid,

Segi Bahasa, persentase tingkat pencapaian $81 \%$ berada pada kualifikasi sangat valid.

\section{Praktikalitas Modul}

Data Hasil Pengamatan Observer Terhadap Pelaksanaan Proses Perkuliahan dengan Modul Berbasis CTL terlihat pada tabel dibawah ini :

Tabel 1. Hasil Validasi Aspek Materi dalam Modul Geometri Analitik Bidang Berbasis CTL

\begin{tabular}{|c|l|c|c|c|c|c|}
\hline \multirow{2}{*}{ No. } & \multicolumn{1}{|c|}{ Aspek Yang Dinilai } & \multicolumn{3}{c|}{ Validator } & \multirow{2}{*}{ Jumlah } \\
\cline { 3 - 6 } & & $\mathbf{1}$ & $\mathbf{2}$ & $\mathbf{3}$ & $\mathbf{4}$ & \\
\hline 1. & $\begin{array}{l}\text { Materi yang disajikan sesuai dengan } \\
\text { kompetensi yang dicapai }\end{array}$ & 5 & 5 & 4 & 4 & 18 \\
\hline 2. & $\begin{array}{l}\text { Konsep-konsep yang diuraikan pada } \\
\text { materi dipertegas dengan gambar, grafik } \\
\text { atau tabel }\end{array}$ & 4 & 4 & 4 & 4 & 16 \\
\hline 3. & $\begin{array}{l}\text { Penyajian materi telah memberikan } \\
\text { kesempatan bagi mahasiswa dalam } \\
\text { menemukan sendiri konsep dan prinsip } \\
\text { yang dipelajari }\end{array}$ & 4 & 4 & 4 & 4 & 16 \\
\hline 4. & $\begin{array}{l}\text { Materi telah disajikan dengan urutan } \\
\text { yang sistematis }\end{array}$ & 4 & 4 & 4 & 4 & 16 \\
\hline 5. & $\begin{array}{l}\text { Materi telah dirumuskan berdasarkan } \\
\text { ciri-ciri berbasis CTL }\end{array}$ & 4 & 4 & 4 & 4 & 16 \\
\hline 6. & $\begin{array}{l}\text { Materi yang disajikan pada modul telah } \\
\text { mengarahkan mahasiswa untuk } \\
\text { mengkonstruk pengetahuannya sendiri }\end{array}$ & 4 & 4 & 4 & 4 & 16 \\
\hline 7. & $\begin{array}{l}\text { latihan relevan dengan materi yang } \\
\text { disajikan }\end{array}$ & 4 & 5 & 4 & 4 & 17 \\
\hline Aspek secara keseluruhan & 29 & 30 & 28 & 28 & 115 \\
\hline
\end{tabular}

Berdasarkan hasil penilaian validator, sebagaimana dicantumkan dalam Tabel 7 , maka dapat dihitung persentase pencapaian modul untuk aspek materi sebagai berikut:

Jumlah skor seluruh item $=115$

Jumlah skor maksimum $=140$ 
Maka persentase $=82,14 \%$. Persentase tingkat pencapaian $82,14 \%$ berada pada kualifikasi sangat valid. Komentar dan saran dari validator dijadikan bahan pertimbangan untuk menyempurnakan modul.

Tabel 2. Hasil Validasi Aspek Penyajian dalam Modul Geometri Analitik Bidang Berbasis CTL

\begin{tabular}{|c|l|c|c|c|c|c|}
\hline \multirow{2}{*}{ No. } & \multicolumn{1}{|c|}{ Aspek yang Dinilai } & \multicolumn{3}{|c|}{ Validator } & \multirow{2}{*}{ Jumlah } \\
\cline { 2 - 6 } & & $\mathbf{1}$ & $\mathbf{3}$ & $\mathbf{4}$ & \\
\hline 1. & $\begin{array}{l}\text { Kompetensi utama dan khusus serta } \\
\text { petunjuk penggunaan modul telah } \\
\text { disajikan secara jelas }\end{array}$ & 4 & 5 & 4 & 4 & 17 \\
\hline 2. & $\begin{array}{l}\text { Secara visual, penulisan konsep, ide, } \\
\text { istilah dan rumus telah disajikan dengan } \\
\text { jelas }\end{array}$ & 4 & 4 & 4 & 4 & 16 \\
\hline 3. & $\begin{array}{l}\text { Penyajian materi telah membahasakan } \\
\text { gagasan yang ingin disampaikan }\end{array}$ & 4 & 4 & 4 & 4 & 16 \\
\hline 4. & $\begin{array}{l}\text { Penyajian materi telah memunculkan } \\
\text { proses pembentukan dan pemahaman } \\
\text { konsep }\end{array}$ & 4 & 4 & 4 & 4 & 16 \\
\hline 5. & Penyajian gambar jelas dan menarik & 4 & 4 & 4 & 5 & 17 \\
\hline 6. & $\begin{array}{l}\text { Materi yang disajikan memberikan } \\
\text { kesempatan untuk mengembangkan } \\
\text { motivasi dalam mempelajarinya }\end{array}$ & 4 & 4 & 4 & 4 & 16 \\
\hline 7. & $\begin{array}{l}\text { Materi yang disajikan membantu } \\
\text { mahasiswa mengungkapkan ide-ide } \\
\text { secara jelas dengan tulisan ataupun } \\
\text { gambar. }\end{array}$ & 4 & 4 & 4 & 4 & 16 \\
\hline Jumlah secara keseluruhan & 28 & 29 & 28 & 29 & 114 \\
\hline
\end{tabular}

Berdasarkan hasil penilaian validator, sebagaimana dicantumkan dalam Tabel 1, maka dapat dihitung persentase pencapaian modul untuk aspek penyajian sebagai berikut:

Jumlah skor seluruh item $=114$

Jumlah skor maksimum $=140$

Maka persentase $=81,43 \%$, persentase tingkat pencapaian $81,43 \%$ berada pada kualifikasi sangat valid sehingga modul tidak perlu direvisi. 
Tabel 3. Hasil Validasi Aspek Bahasa dan Keterbacaan pada Modul Geometri Analitik Bidang Berbasis CTL

\begin{tabular}{|c|l|c|c|c|c|c|}
\hline \multirow{2}{*}{ No. } & \multicolumn{1}{|c|}{ Aspek Yang Dinilai } & \multicolumn{3}{|c|}{ Validator } & \multirow{2}{*}{ Jumlah } \\
\cline { 2 - 6 } & \multicolumn{1}{|c|}{$\mathbf{1}$} & $\mathbf{2}$ & $\mathbf{3}$ & $\mathbf{4}$ & \\
\hline 1. & $\begin{array}{l}\text { Kalimat yang digunakan telah sesuai } \\
\text { dengan kaidah bahasa Indonesia }\end{array}$ & 4 & 4 & 4 & 4 & 16 \\
\hline 2. & $\begin{array}{l}\text { Kalimat yang digunakan melibatkan } \\
\text { kemampuan berpikir logis mahasiswa }\end{array}$ & 4 & 4 & 4 & 4 & 16 \\
\hline 3. & $\begin{array}{l}\text { Struktur kalimat telah sesuai dengan } \\
\text { tingkat pemahaman mahasiswa }\end{array}$ & 4 & 4 & 4 & 4 & 16 \\
\hline 4. & $\begin{array}{l}\text { Bentuk dan ukuran huruf pada modul } \\
\text { telah sesuai dengan kapasitas } \\
\text { keterbacaan mahasiswa }\end{array}$ & 5 & 4 & 4 & 4 & 16 \\
\hline 5. & $\begin{array}{l}\text { Kalimat yang digunakan dalam } \\
\text { penyajian modul tidak memberikan } \\
\text { makna ganda (ambigu) }\end{array}$ & 4 & 4 & 4 & 4 & 16 \\
\hline
\end{tabular}

Berdasarkan hasil penilaian dan tanggapan para ahli dengan tingkat pencapaian diatas $80 \%$ maka pada dasarnya modul masuk kualifikasi valid.

\section{Praktikalitas Modul Berbasis CTL}

1) Pelaksanaan Perkuliahan dengan Modul Berbasis CTL

Hasil observasi terhadap pelaksanaan proses pembelajaran dapat dilihat pada Tabel 4.

Tabel 4. Data Hasil Pengamatan Observer Terhadap Pelaksanaan Proses Perkuliahan dengan Modul Berbasis CTL

\begin{tabular}{|c|l|c|c|c|c|c|}
\hline \multirow{2}{*}{ No } & \multicolumn{1}{|c|}{ Aspek yang diamati } & \multicolumn{2}{|c|}{ Pertemuan } & Jml & $\begin{array}{c}\text { Persentase } \\
(\%)\end{array}$ \\
\cline { 3 - 5 } 1 & $\begin{array}{l}\text { Tercipta situasi kelas yang yang mendorong } \\
\text { mahasiswa untuk saling bertanya, menjawab atau } \\
\text { mengeluarkan pendapatnya }\end{array}$ & 4 & 4 & 4 & 12 & 80 \\
\hline 2 & Membantu siswa memahami modul dan soal-soal & 3,5 & 4 & 4,5 & 12 & 80 \\
\hline 3 & $\begin{array}{l}\text { Adanya interaksi antar mahasiswa ketika mereka } \\
\text { saling bertanya dan menjawab/berdiskusi }\end{array}$ & 3 & 4 & 4,5 & 11,5 & 76,67 \\
\hline
\end{tabular}




\begin{tabular}{|c|l|c|c|c|c|c|}
\hline 4 & Memotivasi mahasiswa selama proses pembelajaran & 4,5 & 4,5 & 5 & 14 & 93,33 \\
\hline 5 & $\begin{array}{l}\text { Menstimulasi mahasiswa untuk mengemukakan } \\
\text { alasan (lisan maupun tulisan) dalam menyelesaikan } \\
\text { soal-soal pada modul }\end{array}$ & 3 & 4 & 4 & 11 & 73,33 \\
\hline 6 & $\begin{array}{l}\text { Menstimulasi mahasiswa dalam mengembangkan } \\
\text { kemandirian dan kreativitas dalam memahami modul } \\
\text { dan menyelesaikan soal-soal }\end{array}$ & 4 & 5 & 5 & 14 & 93,33 \\
\hline
\end{tabular}

Catatan : Nilai $1=$ sangat kurang, nilai $2=$ kurang

Nilai 3 =cukup baik, nilai 4 = baik, $\quad$ Nilai 5 = sangat baik

Ini berarti persentase proses perkuliahan dengan menggunakan modul bernilai dalam rentangan baik dan sangat baik.

2) Hasil Wawancara dengan Mahasiswa Mengenai Praktikalitas Modul berbasis CTL.

Berdasarkan hasil wawancara dapat disimpulkan bahwa modul sudah praktis untuk digunakan.

1.

Efektifitas Modul Berbasis CTL

a. Aktivitas Mahasiswa

Tabel 5. Data Hasil Pengamatan Observer terhadap Aktivitas Mahasiswa

\begin{tabular}{|c|c|c|c|c|c|c|c|}
\hline \multirow{3}{*}{$\begin{array}{c}\text { Aktivitas yang } \\
\text { Diamati }\end{array}$} & \multicolumn{6}{|c|}{ Aktivitas Pada Pertemuan Ke- } & \multirow{3}{*}{$\begin{array}{c}\text { Rerata } \\
(\%)\end{array}$} \\
\hline & \multicolumn{2}{|c|}{$\mathbf{1}$} & \multicolumn{2}{|c|}{2} & \multicolumn{2}{|c|}{3} & \\
\hline & $\mathbf{F}$ & $\%$ & $\mathbf{F}$ & $\%$ & $\mathbf{F}$ & $\%$ & \\
\hline VA & 36 & 100 & 34 & 100 & 35 & 100 & 100 \\
\hline OA & 13 & 36,1 & 10 & 29,4 & 8 & 22,9 & 29,47 \\
\hline WA & 25 & 69,4 & 29 & 85,3 & 31 & 88,6 & 81,1 \\
\hline DA & 19 & 52,8 & 23 & 67,6 & 29 & 82,9 & 67,77 \\
\hline MA1 & 13 & 36,1 & 19 & 55,9 & 20 & 57,1 & 49,7 \\
\hline MA2 & 4 & 11,1 & 2 & 5,9 & 2 & 5,7 & 7,67 \\
\hline
\end{tabular}

Berdasarkan data yang disajikan pada Tabel 5 dapat dilihat bahwa persentase mahasiswa yang melakukan visual activities (membaca modul) adalah $100 \%$ dan writing activities (mengerjakan latihan) adalah $81,1 \%$. Persentase untuk drawing activities (menggambar atau membuat sketsa) adalah sebesar 67,77\%. aspek ini memperoleh kriteria banyak. Ini berarti proses perkuliahan dengan menggunakan modul berbasis CTL berhasil mengaktifkan kedua aspek tersebut.

Oral activities (bertanya pada dosen atau mahasiswa lain) memperoleh persentase sebesar 29,47\% dengan kriteria sedikit. Ini berarti, pembelajaran dengan modul kurang 
berhasil mengaktifkan aspek ini. Mental activities (menanggapi, memecahkan soal, menganalaisis, mencari hubungan dan menyimpulkan pembelajaran) memperoleh persentase sebesar 49,7\% dengan kriteria sedikit. Ini berarti, pembelajaran dengan modul kurang berhasil mengaktifkan aspek ini. Sedangkan motor activities (mengganggu teman, melamun dan bermain) memperoleh persentase sebesar 7,67\%.

b. Hasil Belajar Mahasiswa

Ini berarti lebih dari 70\% mahasiswa mendapatkan nilai lebih dari 65. Berdasarkan kesimpulan tersebut pengembangan modul berbasis CTL pada perkuliahan Geometri Analitik Bidang dapat dikatakan efektif.

\section{KESIMPULAN DAN SARAN}

1) Kesimpulan

a. Validitas Modul Berbasis CTL pada Perkuliahan Geometri Analitik Bidang disimpulkan bahwa hasil validasi dari validator menunjukkan modul berbasis CTL yang dikembangkan adalah valid.

b. Praktikalitas Modul Berbasis CTL pada Perkuliahan Geometri Analitik Bidang menunjukkan bahwa modul berbasis CTL pada perkuliahan Geometri Analitik Bidang sudah praktis. Modul berbasis CTL pada perkuliahan Geometri Analitik Bidang yang digunakan dapat menimbulkan minat belajar dan kreatifitas.

c. Efektifitas Modul Berbasis CTL pada Perkuliahan Geometri Analitik Bidang Program Studi Pendidikan Matematika angkatan 2014 A diperoleh lebih dari 70\% mahasiswa mendapatkan nilai lebih dari 65. Ini berarti modul dapat dikatakan efektif.

\section{DAFTAR PUSTAKA}

- Anas Sudijono.2005. Pengantar Statistik Pendidikan. Jakarta: RajaGrafindo Persada.

- Fauzan, Ahmad. 2002.Applying Realitistic Mathematics Education (RME) in Teaching Geometry in Indonesian Primary Schools.Tesis tidak diterbitkan. Enschede: University of Twente.

- Nyimas Yasmin. 2007. "Pengembangan Perangkat Pembelajaran Matematika Berbasis RME (Realitstic Mahematics Education) Dilaksanakan Secara Terbatas di SD Negeri 24 Padang”. Tesis tidak diterbitkan. Padang: Pascasarjana UNP.

- Sukmadinata. N.S. 2005. Metode Penelitian Pendidikan. Jakarta : PPs UI dan Remaja Rosdakarya.

- Sumadi Suryabrata. 2002. Metodologi Penelitian. Jakarta: RajaGrafindo Persada. 